\title{
ISLAM DI PULO TENGAH
}

\section{ABD. SHADIQ KAWU \\ IDENTIFIKASI DAERAH PENELITIAN}

\section{A. Keadaan Fisik.}

Pulo Tengah, salah satu dusun yang tcrletak dalam wilayah Desa Amassang Kecamaian Polewali Polmas. Terlctak ditengah pulau kccil, dan terpisah dari daratan Bajoe, dacrah pesisir pantai sebelah timur kota Kecamaian Polewali. Untuk mencapai lokasi ini, bisa ditempuh lcwat Binyang, dengan menggunakan perahu bermotor. Pada umumnya pengunjung yang bcrminal ke Pulo Tengah lebih suka melintasi pesisir perkampungan Bajoe, dan menyebcrang ke sana dengan perahu - perahu nelayan yang digunakan untuk menaagkap ikan. Dari pesisir Bajoe ini, Pulo Tengah dapat di jankau hanya sekitar 15 Menit dengan perahu motor kecil.

Dusun ini luasnya 300 hektar, terdiri dari satu buah Rukun kampung, tiga RT dengan jumlah penduduk 456 jiwa, Mereka tersebar di Pulo ini, dengan membangun rumah - rumah sederhana, model panggung. Pada umumnya, rumah tempat kediaman penduduk dibangun dari kayu, beratap rumbia. Secara geografis, dusun ini, terisolir dari pusat aktiftas Desa Amassangan. Sentuhan - senluhan pembangunan fisik, sebagaimana yang sering terjadi di daratan Desa tidak banyak menyentuh kepentingan masyarakat.

Penduduk setempat, terisolasi dalam bcrbagai aspek termasuk pengembangan sektor potensial, seperti sumber daya alam yang belum pernah digarap secara programatis.

Tanah subur disekeliling dusun, dan daerah perbukitan kaya dengan pohon kelapa, jagung, ubi dan rerumputan semak yang mcmbuat rumah rumah penduduk, semakin tersembunyi dibalik rindang pepohonan. Jalur jalan yang menjadi sarana penghubung antar RK maupun RT, tidak ada sama sekali, kecuali jalan - jalan setapak yang ditandai bekas jejak kaki penduduk setempat. Dikclilingi jalan - jalan itu, tumbuh subur daun ilalang, yang mcnulupi permukaan jalan. Dimusim hujan, jalan setapak ini, menjadi becek bercampur lumpur. Kecuali di dekat pusat pemukiman penduduk seperti di sepanjang dacrah " makam Syeh bil Makruf", kelihatan sebidang areal terbuka.Ditempat ini berdiri rumah - rumah penduduk mesjid.madrasah Ibtidaiyah, dan sebuah bangunan panjang tanpa kamar, penuh dengan tempat duduk dari papan yang dibentangkan. Bangunan terakhir ini, adalah tempat beristrirahat para pengunjung yang da tang siarah ke makam Syeh bil Makruf. Tempat ini olch penduduk setempat, dianggap debagai" tempat suci"karena, rangkaian proses upacara kunjungan diselenggarakan di sini, termasuk upacara pemotongan hewan, kerba, ayam dan sebagainya.

Karcna keadaan rumah penduduk belum ditata penempatannya seuap warga dusun yang berniat mendirikan rumah penduduk belum ditata penempatannya setiap warga dusun yang berniat mendirikan rumah, cukup dengan membcritahukan kepada kcpala Dusun,atau pemilLk tanah setempat dan sesudah itu mereka bisa membangun rumah tinggal sendiri.

Pajarai, salah seorang petugas makam, yang merangka khatib dusun menempati rumah yang lebih lumayan dalam ukuran lokal. rumah ini dibangun hanya sekitar lima meter dari pinggiran laut, beratap seng dan berdinding papan. 
Di bawahnya, dibuat kamar-kamar khusus untuk tempat duduk di waktu sore, dan sebuah ruangan untuk kios kecil di Pulo tengah. Dari 456 jiwa penduduk yang menetap di Dusun ini.mata pencaharian utama adalah nelayan. Salu tahun tcrakhir, penduduk yang tinggal dekat pantai, mulai momudifikasi pekerjaan tradisionalnya sebagai nelayan dengan membuka lahan rumput laut di dekat rumah tempat tinggal. Pada walktu malam dan pagi hari, nelayan-nelayan dusun berangkat ke laut, dan kalau tiba di dusun, mcreka bekerja menyiangi lahan rumput laut, atau ada juga diantaranya yang bekerja sebagai petani kelapa.

Sarana kesehatan sangat terbatas, kcuali ada seorang mantri kesehatan yang scring datang ke Pulo untuk mengontrol kesehatan penduduk. Apalagi bangun resmi, seperti puskesmas belum ada. Dalam kondisi seperti ini, dapat dipahami, kalau kesehatan hygienis masyarakat bclum terwujud sebagaimana mulai nampak di pusat Dcsa Amassangan. Penduduk tumbuh dan berkembang secaraalmiah. Kurang mendapalkan pcnyuluhan, dan para petugas dusun, seperti kepala dusun tidak punya peluang umtuk melakukan pembinaan karena mereka sendiri sibuk dalam pekerjaan sehari-hari. Di dusun ini baru ada lima sumur umum, ditambah dua buah sumur pompa, dan WC. Selebihnya, penduduk menggunakan pesisir pantai dan dacrah pohon ilalang yang luas, sebagai tempat pembangunan.

Satu-satunya sarana pendidikan, adalah sebuah madrasah Ibtidaiyah swasta,yang dibangun permanen di samping sebclah timur Masjid. Mushalla ini, tempat anak-anak usia sekolah dasar menuntut ilmu, mngejar isolasi tempat tinggal mereka yang sudah berlangsung lama, sebagai daerah nelayan, pemandangan rutin yang dapat dilihat ditempat ini, adalah perahu-perahu penangkap ikan dengan ukuran kecil. Di waktu pagi, jarang penduduk pria di lihat di pulo. Mereka pada umumnya berangkat kelaut untuk mrnangkap ikan sejak subu dan akan kembali sekitar jam sepuluh pagi. Nelayan-nelayan yang sedang tidak kelaut, pada hari-hari tertentu, biasanya memamfatkan kunjungan pensiarah dari luar untuk menyeberangkan mereka ke Bajoe. Pendapatan dengan jasa penyebrang setiap hari minggu ini, cukup menambah nikmat nelayan. Apalagi kalau pengunjung cukup banyak.

\section{B. Sosial Budaya.}

Masyarakat Pulo Tengah, mewarisi suatu peninggalan budaya yang bervariasi.Sistem budaya (magetsari,1982) yang terdiri dari konsep gagasan-gagasan yang sifatnya abstrak kemudian dikembangkan dalam sistem sosial, dimana gagasan-gagasan itu dijabarkan sebagai norma-normayang mempengaruhipolainteraksi dan prilaku sosial masyarakat.

Hal-hal yang berbentuk sistem budaya, dapat dilihat dalam proses aktualisasi tentang pandangan hidup masyarakat. konsep » kal tentang baik dan jahat dan konsep-konsep lainnya yang bertalian dengan hukum dan hal-hal yang mengatur prilaku individu di tengah-tengah pergaulan sosialnya. Sebagai masyarakat yang terisolasi dari komunitas Desa, penduduk Pula Tengah, mempunyai karakteristik sendiri dalam proses pengembangan sistem budayanya.

Mengingat latar belakang penduduk, yang meskipun kecil, tetapi cenderung heterogen, karena mereka berasal dari kelompok etnis yang berbeda, dan membangun varian kehidupan sosial budaya mereka dalam konteks daerah asal, dalam persentuhan budaya, dimana komunikasi timbal balik terjadi lewat proses interaksi sosial antar penduduk, baik karena persamaan pekerjaan maupun karena pertemuan-pertemuan dipusat-pusat peribadatan, maka mereka cenderung membentuk pola adaptif, dimana 
varian tradisi dan keaneka raganian sistem budaya itu dapat diakomodatif, dan setiap kelompok etnik dapat menerima dan memahaminya.

Satu faktor yang mengikat komunitas Pulo Tengah dalam inlegrasi yang stabil, karena kelompok-kelompok etnik, seperti etnik Bugis, Binuang, Mandar dan satu kelompok kecil yang mengidentifisi diri mereka sebagai orang "To Pulo", mempunyai persamaan sikap terhadap cradisi. Kepercayaan terhadap sejarah Syehk bil Makruf, yang dimakamkan di Pulo ini secara simbolis telah menjadi unsur pendukung solidaritas antar etnik-etnik kecil penduduk Pulo Tengah. Walaupun perkampungan antar etnik, seringkali dapat diidentifikasi lokasinya, misalnya perkampungan orang Binuang di sebelah barat Pulo, dan perkampungan orang Mandar di sebelah timur, tetapi hubungan rutin antar penduduk berlangsung intensif Anter RT, terjadi hubungan kerja sama, terutama menyangkut perbaikan cara hidup, atau kerja sama dalam pembersihan kampung.

Demikian pula setiap kelompok etnik ini dapat berkomunikasi dalam bahasa yang digunakan disana, seperti bahasa Pattae, bahasa Bugis dan bahasa Mandar, termasuk Indonesia. Penduduk dusun, tidak pengunjung, karena mereka dapat saja berkomunikasi dalam bahasa tersebut. Sebagaimana halnya masyarakat yang berkembang dalam isolasi yang lama. Masyarakat disini cenderung sangat panatik terhadap pola-pola lama yang telah dilerima secara turun temurun.

Mungkin karena pengaruh makam Syehk bil Makruf, yang olch penduduk dusun sangat diagungkan, mcnyebabkan pendudukdusun masih percaya dengan ceritera-ceritera yang bcrsifat mistik. Atau legenda masa lampau Pulo ini, walaupun dilain pihak, komunikasi dengan penduduk dari luar sudah berlangsung cukup lama, sebab selain rnudah dijangkau kendaraan kecil lewat laut, juga hubungan mereka dengan penduduk di pusat Kecamatan atau di pusat Kabupaten sudah berlangsung intensif. Tetapi persentuhan itu, tidak melunturkan komitmen mereka terhadap kepercayaan magis yang masih dipegang teguh. Oleh karena itu di dusun ini, tumbuh subur ceritera-ceritera rakyat yang dibumbui dengan kisah-kisah patnotisme, kepahlawanan dan keberanian para penemu Pulo, yang seringkali beberapa bagian dari kisah itu sangat tidak logis dalam logika para pengunjung yang mencoba berpikir kritis.

Memang dipandang dari beberapa aspek, terutama aspek geografis, masyarakat setempat memang memerlukan waktu lama untuk merobah sikap dan cara berfikir mereka, sehingga bisa relevan dengan kondisi sekarang, akan tetapi dilihat dari frekwensi persentuhan dengan komunitas luar, apalagi dengan arus pengunjung yang meningkat setiap bulannya, secara bertahap perubahan itu akan terjadi juga, meski untuk waktu yang agak lama. Masyarakat Pulo Tengah, menganut sistim kekerabatan bilateral yaitu menempu garis kcturunan ayah dan ibu secara seimbang. Hal ini dijumpai setiap kelompok etnik yang mendiami dusun ini. Demikianpun dalam pembagian harga warisan, khususnya sebelum agama Islam, bahagian anak perempuan dan anak iaki-laki dibagi sama rata. Cuma belum ada kepastian catatan tentang kapan sebenarnya, migran dari bcrbagai etnik mulai menetap di Pulo ini, apakah sebelum datangnya agama Islam yang dibawah oleh Syehk Bil' Makruf, dan dimakamkan disana.

Setelah agama Islam dianut penduduk daerah Mandar, terutama dalam wilayah tentorial konfederasi "Pitu Babana Binanga" dimana kerajaan Binuang, termasuk salah satu dianlaranya, maka sistem kewarisan diatur berdasarkan ketentuan hukum Islam, yaitu mengikuli 
jalur, dimana pihak ayah dijadikan patokan. Dcmikian pula, pcnibagian kerja, laki-laki dan wanita dianggap sama. Di dacrah ini, sudah ada pcmbagian tugas aniara wanita dan laki-laki bcrtugas mencari naikah di laut, sedang wanita tinggal menjaga anak dan kcluarga di rumah. Biasanya kaum wanita Pulo Tcngah, ada yang bckcrja scbagai pcnjual barang-barang campuran yang dipasang di bawah kolong rumah, atau bertenung sarung sutcra (khususnya clnik Mandar) dan ada pula yang siap menunggu suami dan bcrtugas untuk mcmasarkan hasil tangkapan ikan dari laut.

Di daerah Kcrajaan Binuang, scbagai salah satu bahagian dari daerah Mandar, hak dan kcwajiban antara pria dan wanita tidak perlu diklasipikasikan sccara formal, akan tctapi antara laki-laki dan wanita sudah ada pola budaya yang harus diikuti. Bahwa scmua pckcrjaan yang menyangkut kcpentingan kcluarga dapat saja dilakukan kaum wanita, terutama bila kaum lakilakinya memang momerlukan bantuan dalam pckcrjaan itu.

Pola kekerabatan masyarakat dusun tidak hanya berdasarkan keturunan, tctapi juga bisa berlangsung dalam bcntuk karcna hubungan pribadi yang sangat intim. Tctapi pola kekerabatan sccara umum terjadi, mclalui perkawinan. Akibatperkawinan an tar etnik,sckarang ini sudah sulit untuk mengidentifikasi sccara tajam antar lalar belakang kelompok ctnik. Hubungan itu kemudian telah mewujudkan suatu komunitas baru, yang disebut to Pulo (artinya, orang yang tinggal di Pulo Tengah).

Apabila penduduknya bepcrgian kc luar daerah ini, keluarganya di luar pulo akan menyebutnya, to pulo, atau to pole-pulo (orang yang datang dari pulo). Identifikasi ini, secara tidak langsung sudah mengurangi scbyektifisme ctnik, yang pada mulanya sangat tajam, sehingga membcda bedakan antara pcndatang dari Mandar, Bugis, ataupun dari Pattae. ${ }^{3}$

Satu satunya pola identifikasi berdasarkan clnik di dacrah ini adalah penggunaan bahasa dacrah masing-masing kelompok etnis yang masih dipakai dengan bcbas. Walaupun seperti telah dikemukakan, apabila warga setempat bcrkomunikasi dalam jaringan sosial yang lebih luas, semua bahasa daerah yang digunakan kelompok-kclompok pendalang bisa berfungsi scbagai bahasa pengantar.

\section{Sejarah Desa.}

Pulo Tengah, pada mulanya adalah sebuah pulo kccil yang terpisah dari daratan Kabupaten Polmas. Mcnurut kcterangan salah scorang informal) 3 di Dusun ini, bahwa daerah ini belum didiami manusia scbagai daerah pemukiman, pada pcrtengahan abad kc-17. Sebab dalam sejarah Kcrajaan Binuang ${ }^{4}$, disebutkan bahwa pulau-pulau kccil yang terletak di sekitar darautn Polcwali, seperti: Pulau Tengah, Pulau Nusa Indah, dan Pulau Karamasnang, belum didiami manusia sebagai tempat tinggal tetap, kctika Syehk bil Makruf, penganjur agama Islam pertama di dacrah Binuang datang di Kerajaan Binuang.

Ceritcra rakyat yang berkembang di Desa Amassangan, menyebutkan bahwa, kedatangan Syehk bil Makruf di Kerajaan Binuang, melalui

\footnotetext{
1. Pola distribusi pckcrjaan bagi penduduk pria dan wanita tidak ada batasan yang jelas. Pembagian kerja, pria ke laut dan wanita menangani urusan rumah tangga, hanyalah merupakankebiasaan yang sudah lama. Tetapi masyarakat setempat tidak juga menegaskan bahwa kaum wanita dilarang pergi kelaut. Namun sampai penelitian ini dilakukan belum ada yang melakukannya.

2. Wawancara Uaji Abd.Malik, mantan anggola DPR Rl di Polcwali pada tanggal 3 Juli 1990.

3. Rurun.B, salah seorang penduduk Dusun Pulau Tengah yang sudah menetap hampir lima puluh tahun di Dusun itu.

4. Paliwang Tandilangi, dalam makalahnya lentang Proses penyebaran agama [slam di Kcrajaan Binuang.
} 
Laut dari Gowa. Ia ditemukan dipesisir pantai Binuang oleh seorang nelayan dan kemudian setelah meninggal dunia, ia ditemukan penduduk Pesisir Pantai Pulau Karamasang, sendirian.

Pemukiman diperkirakan mulai berlangsung, pada sekitar awal abad ke-18 ketika agama Islam mulai berkembang di Pulau Pulauan sekitar Kerajaan Binuang. Terutama ketika Jenazah Syehk bil Makruf ditemukan dan kemudian di makamkan di Pulau Tengah. Pupularitas Syehk bil Makruf menarik perhatian penduduk di daerah sebelah sekitar kerajaan Pitu Babana Binangan.

Oleh karena pemukiman pcrtama di daerah ini ada yang berasal dari Kecamatan Tinambung, Majene, Campalagian dan dari daerah sekitar Kecamatan Polewali. Jumlah migrasi dari Tinambung dan Majene bertambah ketika terjadi kekacauan di Kabupaten Polmas, dan Majene akibm gerakan Darul Islam, sekitar tahun $1952 .^{6}$

\section{DESKRIPSI HASIL PENELITIAN}

A. Kehidupan Keagamaan.

Agama, dalam pengcrtian doktrinal adalah pemberian atau wahyu dari Tuhan, tetapi ketika ajaran agama ditransmissikan dalam komunitas tertentu, maka teks-teks murni yang merupakan refleksi dari wahyu itu telah berbaur dengan proses sekularisasi. Ia meliwati jalur budaya, dalam hal mana, agama dalam proses penyebarannya telah terlibat dalam mekanisme gcrak sosial yang bersifat kontemporer.

Sejauh mana agama, mengalami perubahan dalam dirinya, baik secara doktrinal maupun secara operasional (budaya) khususnya ketika terjadi persentuhan dengan aspek-aspek budaya, atau sejauh mana agama memberi kontribusi tertentu terhadap perubahan sosial di sekitarnya, akan dicobah dikemukakan dalam laporan ini. Perubahan sosial, adalah salah satu keharusan yang menandai gerak dinamika suatu kolektiva masyarakat. Sementara masyarakat tak hentihentinya melakukan penyesuaian internal sementara itu peradaban manusia terus berubah. Suatu petunjuk bagi segenap manusia di dunia untuk selalu memiliki kecenderungan berubah. (Eismedtat, 1986:65) Walaupun telah antropologi tahun tiga puluhan empat puluhan dan lima puluhan menggambarkan bahwa masyarakatmasyarakat primitif secara umum memiliki sedikit sekali kecenderungan kearah perubahan dan khususnya perubahan transpormatif (yaitu perubahan dalam premis-premis kelembagaan yang ada), namun diakui bahwa dalam masyarakat tersebut telah dijumpai konflik dan kontrafiksi konflik antara golongan masyarakat dan kontradiksi mengenai prinsip organisasi sosial, khususnya mengenai pertalian keluarga (kinsnip batas wilayah dan batas kekuasaan (Eisndestat, $1986: 65)$.

Secara umum, berdasarkan keterangan tersebut, dapat diketahui bahwa, perubahan sosial cenderung terjadi dalam suatu komunitas sosial, terlepas dari bagaimanapun ungkat atau bentuk komunitas itu. Salah satu faktor yang melatar bclakangi atau menjadi indikator dari perubahan itu adalah agama. Terutama setelah agama yang dipeluk masyarakat tertentu telah meliwati proses transmissi yang panjang, sehingga ia mengalami perubahan baik dalam materi ajaran, maupun dalam bentuk ritual yang diselenggarakan oleh penganutnya. Untuk mengetahui perubahan itu,' perlu dikemukakan beberapa aspek yang merupakan latar belakang kehidupan keagamaan masyarakat di Pulo Tengah.

5. Ada pendapat yang mengatakan, bahwa Syehk bil Makruf adalah penyebar agama Islam pertama di daerah Mandar.

6. Gerakan pengacauan gerombolan Darul Islam yang dipimpin Kahar Muzakkar pernah berpengaruh sangat dalam terhadap masyarakat Mandar, terutama sekitar tahun 1952. 
Masyarakat Pulo Tengah, pada dasamya masih termasuk masyarakat yang sederhana. Walaupun tidak lagi sepenuhnya dapat dikategorikan dalam Kriterium Riggs tentang manusia yang memandang dunia sebagai sesuatu yang hanya dapat dipahami dalam pengertian yang bersifat suci, supernatural, dan personal, (Hoggvclt, 1985: 204), namun beberapa ciri masyarakat Pulo Tengah menunjukkan bahwa mereka belum bisa dikategorikan dalam komunitas manusia modern yang bersikap sekunder dan rasional terhadap kepercayaan.

Kehidupan sehari-hari ditandai, komitmen yang tinggi terhadap agama dalam konteks yang mereka pahami secara sangat sederhana. Agama cenderung dipahami sebagai rcverensi dalam kehidupan yang serba ganda. Disatu pihak, mereka pcrcaya bahwa agama adalah "way of life" tetapi hal ini tcrbatas pada kepercayaan formal, yang bahkan belum menjangkau secara operasional, yang terwujud dalam kehidupan rutin sehari-hari. Dipihak lain, agama adalah jalan mistik, tempat masyarakat mengadukan harapan dan kekecewaan sehari-hari. Salah satu sarana pcndukung untuk menginlensiikan penduduk setempat pada upacara-upacara seperti ini, adalah makam Sychk bil Makruf. Indikator ini, nampak dengan sikap hormat penduduk terhadap makam, kebiasaan mengunjungi makam pada hari-hari tcrtentu, dan dalam beberapa hal penduduk Pulo Tengah ikul larut dalam upacara siarah yang disclenggarakan olch pengunjung ke Pulo Tengah.

Pola pola kehidupan keagamaan berkembang menurut pola tradisional yang menurut Pajarai', sudah diwarisi dari generasi penyebar Islam di Kerajaan Binuang, Syekh bil Makruf pada akhir abad ke-17. Pada hari Jum'at, azan dilakukan dua kali pertama, pada Jum'at sudah mulai masuk, dan kedua pada waktu khatib (katte) sudah berada diatas mimbar siap membaca khutbah.

Sistem upacara keagamaan, dilaksanakan dalam bentuk selamatan ${ }^{2}$, khitaban ${ }^{3}$, dan beberapa keluarga yang mempunyai kemampuan secara ekonomik, mengadakan bacaan barsanji setiap malam Jum'at dengan mengundang tetangga terdekat, untuk upacara makan bersama.

Meskipun didusun ini, upacara khitaman AlQur'an, juga diselenggarakan sebagaimana halnya di daerah-daerah lain di Desa Binuang, suasana penyelenggaraannya, tidak sama meriahnya. Hal ini antara lain disebabkan jumlah penduduk yang tcrbatas, dan keadaan pulau yang belum ditata, pola-pola pemukiman penduduk secara terencana. Rumah-rumah penduduk yang terpisah berdasarkan kelpmpok etnik, dibatasi tumbuh-tumbuhan rindang, pohon kelapa, dan semak-semak yang tumbuh subur, termasuk keadaan tanah yang berbukit-bukit, menyebabkan seluruh arcal pemukiman penduduk tidak dapat dipersatukan dalam suatu pemukiman terbuka dan lapang. Namun demikian, komunikasi penduduk di bidang keagamaan cukup tinggi. Apalagi sarana ibadah satu satunya, adalah masjid yang tcrletak di pinggiran Pulo sebelah uUtra. Masjid ini sekaligus berfungsi sebagai tempat menjalin solidaritas dusun dan solidarilas keagamaan. Pada hari-hari Jum'at, Masjid biasanya penuh, seorang petugas masjid yang berfungsi mengatur jalannya ibadah keagamaan, akan selalu nampak mengkoordinasi persiapan pcrsiapan shalal jamaah.

Ada kepercayaan setempat, bahwa petugas "katte" (khatib), cenderung didclegasikan pada

\footnotetext{
1. Parajai, adalah khatib (Katte) formal Dusun Pulo Tengah

2. Selamatan, biasanya diselenggarakan pada upacara syukuran (inisiasi) dan pada waktu mau melakukan upacara perkawinan.

3. Acara khitanan, biasanya diadakan pada bulan Rabiul Awal, sekaligus memperingati Maulid Nabi.
} 
pejabat resmi yang sudah diangkat berdasarkan pengakuan masyarakat. Ratte ini berfungsi seumur hidup, dan hanya diganli manakala yang bersangkutan, temyata tidak mampu lagi melaksanakan tugasnya, atau sudah moninggal dunia. Jadi, khatib (katte) pada penyelcnggaraan sholat Jum'at, secara otomatis di laksanakan pelugas yang diberi wewenang. Selain membaca khutbah khatib sebenarnya berfungsi scbagai koordinalor bidang keagamaan.

Pada umumnya, yang menjadi imam, waklu shalat jamaah juga dipercayakan kepada Khatib, demikian pula, untuk mclayani parapengunjung yang datang bersiarah. Khatib dalam hal ini, bcrtugas untuk membaca doa dan menjadi pcrantara khusus suatu proses hubungan spiritual antara pengunjung makam dengan Tuhan Yang Maha Kuasa. Sctiap pengunjung yang datang kc Pulo Tengah, bisa saja menyampaikan hajathajat tcrtentu, tctapi hajat tersebut terlcbih dahulu diselcksi oleh Khatib, dan Khatib ini pulalah yang akan mcnentukan, apakah perminlaan pengunjung untuk siarah kc Pulo Tengah dapat dipenuhi atau tidak. Adapun syarat-syarat untuk hajat yang bisa diteruskan atau di doakan, di depan makam S yehk bil Makruf, adalah doa atau permintaan itu tidak dimaksudkan untuk tujuantujuan kcjahatan. Scbagai unsur pemcrsatu agama di Pulo Tcngah, menjadi forum solidaritas yang bisa menghilangkan faktor-faktor konflik yang mungkin saja limbul. Akuvilas anggota masyarakat pada waktu sholat jamaah pada waktu upacara perkawinan, selamatan, dan kematian, mempcrerat hubungan silaturrahmi. Dengan adanya pcrtcmuan seperti ini, kctegangan sosial yang bisa timbul karcna biasa dari pergaulan sehari-hari dapat diredam dengan forum-forum keagamaan.

Sctiap ada perselisihan, diantara penduduk pulo, selalu dikonsultasikan lewat Katie, atau kepala Dusun. Lebih dari pada itu, hubungan moral antara semua warga dusun sangat akrab, walaupun komunikasi rutin sctiap harinya tidak kclihatan intensif, bcrhubungan perbedaan latar belakang mata pencaharian.

Masyarakat setempat juga masih pcrcaya pada pctunjuk-pctunjuk yang dipcroleh lewat mimpi. Salah seorang penduduk tertua Dusun ini bcrnama Kurun.B, pcrnah menuturkan mimpinya ketemu dengan Syehk bil Makruf bebcrapa kali. Mimpi itu disampaikan kepada penduduk sckitarnya, dan semua warga dusun mcmpcrcayai mimpi itu scbagai pcringatan dari "Tosalama" (orang kcramat).

"Mimpi bagi kami, adalah pctunjuk yang masih dapat dibuktikan kebenarannya. Anchnya saya sendiri yang sclalu mimpi ketemu dengan To Salama. Pernah awal tahun 1990, saya didatangi To Salama dalam tidur. Ia datang kepada saya dengan muka masam, wajahnya pucat dan dibalik kcrudung jubahnya yang putih ia kclihatan scdang mcrisaukan scsuatu. Tiba-tiba ia berkata kepada saya bahwa penduduk harus bcrhati-hali, hubungan dengan Tuhan harus dibaharui. Karena kalau penduduk Pulo Tengah melupakan tuhan, dalam waklu dekat, akan datang bencana dari Allah SWT untuk mcmpcringati mereka".

Nurun.B, yang sckarang bcrumur 67 tahun, sangat percaya akan kckeramatan Tosalama. Apalagi hubungan batinnya lewat mimpi dengan tokoh spiritual yang dipuja penduduk setempat ini, mcningkatkan statusnya ditcngahtcngah masyarakat. Sctiap pada masalah, atau masyarakat merasakan adanya krisis atau ketidak seimbangan di dalam alam sekilamya, maka mereka akan mendatangi Nurun.B, untuk menany akan, apakah peristiwa-pcristiwayang akan tcrjadi ini, sudah pcrnah disampaikan Tosalama scbelumnya.

4. Orang Pulo Tengah, menyebut syekh bil Makruf dengan Tosalama artinya orang yang memiliki kekcramalan dan keajaiban. Mereka sendiri merasa janggal menyebul nama langsung lokoh ini, karena merupakan suatu pelanggaran etnis. 


\section{B. Keadaan Pengunjung Makam.}

Makam Syehk bil Makruf, satu-satunya makam yang dikcramalkan penduduk di Dusun Pulo Tengah.

Arus pengunjung juga cukup tinggi dibanding dengan tempat-tempat kunjungan wisata lainnya di Kabupaten Polmas. Menurut data yang diperoleh dari petugas makam, setiap bulannya arus pengunjung ke Pulo ini mencapai 2500 orang. Jumlah ini sudah termasuk rendah, dan kadang kala sampai tiga ribu orang.

Pada waktu penelitian diadakan, bulan Juni 1990, jumlah pengunjung yang sudah datang ke lokasi makam, mencapai 22600 orang, padahal waktu itu masih tanggal 14 Juni. Diperkirakan, menurut Marwiyah5, jumlah itu pada akhir bulan bisa meningkat dua kali lipat.

Latar bclakang daerah pengunjung bcrvariasi, mulai dari kecamatan Polewali, Wonomulyo.Campalagian, Tinambung, Majcnc, Pamboang, Sendana, Kabupaten Pinrang, Parc-Pare, Barru, Maros, Ujung Pandang, Soppeng, Bone, Luwu dan Kalimantan, bahkan adajuga pengunjung yang scngaja datang dari Malaysia untuk melakukan siarah ke Pulo ini.

Jumlah pengunjung yang paling banyak adalah nelayan, yaitu 1205 orang, petani 645 orang, pedagang 376 orang, pejabat 25 orang dan pimpinan pesantren 12 orang. Dilihat dari identifikasi pckcrjaan dan status sosial terscbut dapat diketahui bahwa variasi kunjungan ini juga berbeda bcda berdasarkan pekerjaan atau status sosial terscbut. Pada umumnya 12 orang pimpinan pesantren yang bersiarah ke makam ini, menurut informasi yang diperoleh di Pulo Tengah, maksudnya untuk mclihat dari dekal bekas peninggalan scjarah Islam di daerah ini. Merekajuga mencatat, keadaan makam, sejarah dan bagaimana perhatian masyarakat dan pemerintah terhadap perawatan makam. Scdangkan pengunjung dari golongan pejabat terdiri dari
Kcpala Kantor Departemen Agama, Kepala Kantor Departemen Pendidikan dan Kebudayaan, Pcnilik Kebudayaan, Kecamatan Polewali, Balai SukaSejarah dan Kepurbakalaan Propinsi Sulawesi Selatan, dan Staf Bagian Kesra Kantor Daerah Tingkat II Polmas, termasuk Kcpala Kecamatan, Kepala Dcsa dan Pemuka masyarakat.

Untuk mengctahui pengunjung yang benarbenar datang melakukan siarah hajatan, artinya berkunjung karena motivasi tertentu, dapat diketahui dari kelompok (2), (4) dan, (5) diatas yaitu pedagang, petani, nelayan dan petani. Banyaknya nelayan yang berkunjung karena pada umumnya lokasi ini ditengah pulau. dan para pendatang juga berasal dari perkampungan nelayan di daerah pesisir Selat Makassar.

Satu hal yang dapat dilihat dari kedatangan semua pengunjung ke lokasi ini adalah sikap penghormatan yang diperlihatkan setiap pensiarah, tanpa mclihat Latar belakang maksud atau tujuan kesana. Para pejabat pemerintah, biasanya dari bahagian Kesra Kantor Daerah Tingkat II Polmas, atau dari Departemen Agama dan Departemen Pendidikan dan Kebudayaan Polmas, pada dasarnya mereka udak hanya sekedar berkunj ung mclainkan ikut menyaksikan bagaimana proses ritualisasi pengunjung itu berlangsung, dan biasanya mereka ikut juga mcnikmati hidangan-hidangan yang sengaja dipersiapkan pengunjung yang punya kaul tertentu.

Bagi para pengunjung kategori ini, datang ke Pulo Tengah, j uga bisa bcrf ungsi rekreasi, apalagi pada hari-hari minggu atau hari-hari libur lainnya.

Solidaritas yang diperlihatkan oleh kelompok pensiarah setiap orang yang datang pada waktu bersamaan nampak cukup tinggi. Walaupun scbelumnya, tidak saling mengenal, tetapi mereka yang mempunyai kaul dan mem- 
persiapkan hidangan khusus berupa daging kcmbing dan ayam, dengan senang hati akan mengajak setiap orang yang berada di kompleks makam untuk menikmati bersama hidangan itu. Sesudah acara makan ini, mereka akan mendaki tangga tangga permancn yang panjangnya sekitar 20 meter, tempat dimana makam Syehk bil Makruf dihubungkan dari permukaan laut.

Satu hal yang monarik untuk di pahami dari variasi pekerjaan pengunjung yang datang ke Pulo Tengah, adalah banyaknya atau dominannya pekerjaan nelayan dibanding dengan Petani. Ini dapat dimaklumi, dengan terlebih dahulu melihat bagaimana komplcksnya kehidupan nelayan dalam menghadapi tantangantantangan alam yang digumulinya setiap kali mereka berangkat ke laut. Nelayan adalah pekerjaan yang menuntut ketabahan, kebcsaran jiwa, dan juga sportivitas. Berbeda dengan Petani, yang jumlahnya berada diperingkat ke dua sesudah nelayan (645 orang), Nelayan lebih cenderung pada ritus-ritus yang berorientasi mistik. Perjuangan ditcngah laut, dengan hasil yang tidak pernah pasti mendorong para nelayan lebih bersifat spekulatif dalam menghadapi pekerjaan pekerjaan rutinnya. Kelergantungan kepada alam, dan kekuatan-kckuatan simbolik yang mereka pahami di dalam alam, membuat para nelayan lebih banyak mendalami pendekatan-pendekatan yang bersifat supernatural.

Sesuai dengan kepercayaan nelayan di daerah pesisir Selat Makassar, dan pengunjung Pulo Tengah yang berasal dari pesisir pantai Tcluk Mandar, laut nampak begitu luas. Ia bisa didekati dengan cara-cara mistik, dengan doa-doa dan praktek praktek simbolik yang sebenarnya tidak masuk akal, akan tetapi sangat mereka pcrcayai.

Jumlah pengunjung yang diidentifikasi dalam label diatas sebanyak 2510 orang, berdasarkan data pengunjung yang mempunyai tujuan tujuan tertentu yang sifatnya pribadi. Dalam hal ini, pengunjung dari kategori pejabat pemerintah, dan pimpinan pesanlren tidak dimasukan dalam jumlah frekwensi total, karena kelompok hanya berkunjung untuk maksud maksud dinas dan study perbandingan.

Pada label 3 diatas dapat diketahui frekwensi harapan pengunjung yang datang siarah ke makam Syehk bil Makruf sesuai tabel tcrnyata terdapat 1210 orang pengunjung yang mengharapkan adanya perubahan pola hidup dalam rumah tangga mereka. Kelompok ini berkunjung dan berdoa di dalam makam agar dengan doa tcrsebul, kehidupan mereka pada hari-hari yang akan datang bisa berubah lebih baik dari pada pola hidup yang dialami selama ini. Pada peringkat ke dua, yaitu mereka yang datang untuk mendoakan kesembuhan dari penyakit menahun yang sudah lama diderita. Penyakit-penyakit seperti ini, pada umumnya sudah dilangani secara medis, tetapi tidak monunjukkan kesembuhan. Karena mercsa frustrasi, Kelompok ini mongunjungi makam Pulo Tengah, dan mengharapkan kunjungan itu penyakit yang mereka derita selama ini dapat disembuhkan. Jumlah kelompok kategori ini ada 683 orang. Pada urutan ketiga adalah pengunjung yang mengharapkan "lain-lain", termasuk untuk meminta doa keselamatan, atau yang meminta ilmu-ilmu mistik, dan pengunjung yang meminta "nomor jitu SDSB". Kelompok kategori terakhir, yaitu pengunjung yang meminta agar segera mendapatkan jodoh. Kelompok ini tcrdiri dari laki-laki dan wanita yang belum berkeluarga, dan beberapa diantaranya ada yang sudah berstatus duda atau janda. Kelompok ini jumlahnya 143 orang.

\section{Pelaksanaan Upacara Siarah.}

Ritus Keagamaan, bukan sekedar formalitas, tetapi ia mencakup makna dan tujuan sim- 
bolik yang sangat dalam. Ritus adalah manifestasi dari keinginan-keinginan yang hondak dicapai seseorang alau satu kelompok, dengan mcnggunakan media supernatural atau dengan membujuk pada kekuatan-kekuatan non fisik yang diyakini bisa membantu mencapai tujuantujuan tersebut.

Sebuah contoh menarik, bagaimana upacara keagamaan difahami dalam makna-makna simbolik, pernah diungkapkan dalam penelitian Geertz (dalam Roberscon, 1988:240), ketika Gcertz menganalisis upacara Riyaya, yang datang sebagai klimaks bulan puasa mampu memperpadukan di dalamnya kescluruhan kepercayaan dan praktck keagamaan yang menjadi ciri masyarakat Mojokuto. Abangan, santri dan priyaji; nasional yang menggebugebu maupun tradisionalis yang mengalami kcmerosotan; pctani, pedagang, dan pcgawai di kota dan orang desa scmua bisa menemukan simbol yang sesuai bagi mereka dalam perayaan rakyat yang paling sinkretik ini.

Geertz, kemudian mendeskripsikan bagaimana tindakan ritual sentral dalam Riyaya adalah meminta maaf secara pribadi yang dipolakan menurut perbedaan status. Anak-anak meminta maaf pada orang tuany, yang muda kcpada yang iua, buruh kcpada majikannya penggarap kcpada pemilik sawah, politikus kcpada Kclua partainya, bekas murid kepada pondok kepada kiyaonya, Pasien yang tersembuhkan kepada dukungnya murid kistik kepada gurunya. Tiap orang yang statusnya (relatif) rendah ini pcrgi ke rumah yang statusnya lebih tinggi disana ia diterima yang biasanya disuguhi teh dan makanan kccil, dan secara resmi ia minta maaf kepada tuan rumah (Gertz, dalam Roberston, 241).

Makna suatu ritus keagamaan, kalau di Mojokuto, dalam Riyaya, mengandung unsur pcnghormatan kcpada sesuatu yang lebih tinggi, juga nampak dalam ritus khusus di Pulo Tengah. Pengunjung, yang datang dengan berbagai latar bclakang dan status sosial, bertemu di kompleks makam. Mereka duduk dengan tenang, khidmat. Karcna tidak ada tempat duduk yang disediakan, kecuali tembok-tembok pembatas makam di puncak bukit, pengunjung duduk berjongkok di luar ruangan makam, dan pengunjung yang bertindak selaku aktor dalam penyampaian doa doa tcrtcnlu ini, duduk bersilah di dalam makam. Mereka biasanya membawah selembar tikar kecil atau lembaran koran tua untuk diduduki. Sebelumnya disamping makam, mereka duduk dengan penuh sopan santun, solah olah sedang berada di depan orang yang sangat dihormati, dan menyaksikan kehadiran mereka secara fisik. Unsur penghormatan kepada "to salama", mcmang sudah diperaktekkan sejak mereka berangkat ke Pulo Tengah. Berjalan di sekitar kompleks, dan menahan diri dari pembicaraan yang tidak penting, merupakan salah satu upaya membersihkan jiwa dan hati pengunjung dari kotoran kotoran batin. Menurut kepercayaan para pesiarah, pengunjung tang hatinya kotor dan tidak dapat dibersihkan setelah berada di kompleks makam, maka kunjungannya ke sana akan sia-sia. Scbab "to selama" tidak berkenang mendengarkan harapan harapan yang disampaikannya.

Duduk bersilah bagi orang yang sedang mcmbaca doa di samping batu nizam, dan duduk berjongkok, ketika berada di luar makam, menunjukkan belapa penghormatan kepada kekuatan supernatural sedang diperagakan secara aktual. Dalam upacara ini, adaindikator tentangpenyerahan diri secara total manusia yang pasrah dan lemah terhadap "to salama" sebagai wujud kekuatan kekuatan supernatural yang dapat diamati secara fisik walaupun hanya dalam bentuk makam.

Dari latar belakang pengunjung, baik dari pekerjaan maupun tingkat pendidikan dapat 
diketahui betapa besar ketergantungan mereka terhadap kekuatan non fisik yang difahami secara transendentai. Tuhan maha Pencipta begitu besar dan agung, pendekatan langsung terhadapnya sering kali mereka pahami sebagai kelancangan, oleh karena itu, akan lebih aman kalau dengan melakukan ritus makam di kompleks Syehk bil Makruf. Bagaimana deskripsi ritus pengunjung, dapat dikemukakan berikut ini, sebagaimana diamali pcnulis terhadap seorang pengunjung, dari Malili Kabupaten Luwu :

"Hariah, seorang wanita berusia (50), bersama suami dan dua orang anaknya yang pertama, bernama Umar (26) dan yang kedua Linda (19), sengaja datang dari Malili untuk mengunjungi makam Syekh bil Makruf. Hariah dan suaminya adalah pasangan suami istri petani tradisional di Malili. Schari-hari istrinya bekerja menjadi penjaja sayur sayuran di pasar desa. Ia berniat ke Pulo Tengah sejak dua tahun lalu, Kelika ia berhasil mendapatkan bantuan modal kecil untuk jualan barang campuran dari BRI Rp.200.000,- waktu ia berjanji, kalau modal itu bisa dikembalikan dan ia bisa melanjutkan usaha ini lebih baik, ia bersama keluarga akan bersiarah ke makam Syekh bil Makruf. Kctika harapan itu, dua tahun kemudian ia menjadi kenyataan.usahanyaterusbertambah.Iapun datang ke Pulo Tengah.

Dengan mencarter sebuah perahu nelayan di Bajoe, keluarga itu menyeberang ke Pulo Tengah. Pertama kali ia menghubungi Katte (Pajarai), dan kemudian oleh Pajarai, ia diantar kelempat peristirahatan khusus di kaki bukit, tempat makam Syekh bil Makruf di bangun. Di sana ia bersatu dengan pengunjung lainnya. Selesai masak daging kambing dan tiga ekor ayam, pasangan ini makan bersama, setelah Pajarai membaca doa selamat. Kctika dibaca doa, Hariah bersama suaminya mengangkat tangan dan matanya terkatup. Selesai makan, keluarga ini mencapai tangga tangga ke puncat bukit. Di sana ia membawah selembar kain putih dan diikatkan di atas kepala batu nizam. Suaminya hanya duduk di luar makan bersama anaknya, scmentara Hariah masuk ke dalam dan duduk di atas sehelai tikar. Ia mengatakan kepada Pajarai, pembaca doa letap agar kalau dua tahun lalu di sampaikan, dan kedatangan ke Pulo Tengah untuk melepas kaul itu karena Tuhan mengabulkan permintaannya".

Ketika doa selesai di baca, kain putih itu ditarik kembali dan dibcrikannya kepada Pajarai. Ketika bcrsalaman, sebelum turun ke bawah, Hariah menyelipkan selembar sampul berisi uang kepada Pajarai. Sepintas lalu, ritus Hariah bersama keluarga tidak lebih dari upacara rutin yang tidak mempunyai maknakeagamaan. Akan tetapi bagi pelakunya ritus itu sekaligus bermaksud mengintensifkan kembali hubungan ini dengan kekuatan-kekuatan yang transendentai, dan finalnya ialah kepada Tuhan, sebagai Pencipta dan penugasan alam semesta.

Memperbaiki hubungan dengan Tuhan, adalah bcrarti berdoa dan berusaha agar kemudahan yang telah dibcrikan selama ini dapat dipertahankan dan yang lebih penting, bagaimana bisa dikembangkan, sehingga pola kehidupan rumah tangga mereka menjadi lebih baik dari pada apa yang ada beberapa waktu lalu.

Bagi Gecrtz, seperti dikemukakan dalam penilaiannya terhadap ritus Riyaya, upacara seperti ini, tidaklah semata mata untuk berkomunikasi dengan motif-motif religius, tetapi juga 
mengandung pengcrtian untuk mondemonstrasikan kembali kcbcrhasilan yang mereka peroleh selama dua tahun terakhir. Menurut Gertz (1988), meskipun ada aspek keagamaan yang seninal pada ritual minta tersebut, kunjungan itu bagi banyak orang bukan urusan yang tcramat serius. Setiap orang hampir pasti membeli pakaian baru untuk Riyaya sebagaimana halnya kita lakukan untuk hari paskah, dan menyiapkan hidangan yang paling enak menurut kemampuan untuk disuguhkan kepada tamu tamunya. Jadi pola kunjung mengunjungi itu merupakan kesempatan untuk memamerkan pakaian dan hidangan islimewa disamping kesucian upacara; hari itu adalah hari sekaligus hari libur. Orang bcrjalan bergcrombol gerombol sepanjang lorong dan jalan raya, masuk rumah dan keluar rumah, mampir pada masing-masing sekitar lima belas atau dua puluh menit, hingga bcrjumlah sekitar selusin schari, kadang-kadang malah dua lusin.

Sccara teoritis, mungkin kesimpulan Geertz itu, dalam kretika Riyaya, ada benarnya, tetapi dalam upacara siarah makam di Pulo Tengah, pcrnyataan itu patut diragukan. Scbab terlihat proses kunj ungan Hari all bcrsama keluarga, tidak nampak adanya kcinginan untuk memamerkan pakaian. Bahkan Hariah sekeluarga datang dengan pakaian sedcrhana. Baju Kebaya bcrwarna putih pucat, sarung batik yang sudah lusuh dan rambutnya yang kc kuning kuningan di sisir sekedarnya. Hariah ucapan Linda anak pcrempuannya yang masih duduk dibangku kelas terakhir SMA swasta di Palopo juga tidak mengenakan perhiasan emas.

Scekor kambing dan bebcrapa ekor ayam yang dibawanya kc Pulo, hanyalah scbagai persyaratan dari kaul yang pernah di rencanakan kctika ia berspckulasi memulai usaha baru dengan modal bantuan dari BRI. Satu satunya makna upaya Hariah untuk berkomunikasi sc- cara posilif dengan pengunjung lainnya, dan kescdiaannya memberi makan penduduk Pulo, dan pengunjung kebetulan sedang berada di kaki bukit tempat makam.

Hariah juga memberikan sumbangan berupa uang sepuluh ribu rupiah yang dimasukan ke kotak dari kay u yang disiapkan di tempat makam. Sumbangan itu adalah untuk membangun dan kcpcrluan biaya rutin masjid dan perawatan makam. Solidaritas ini, nampaknya telah menjadi semacam kecenderungan setiap pengunjung yang datang ke Pulo Tengah. Mungkin karena adanya perasaan senasib, karena saling mengharapkan kontak religius dengan Syekh bil Makruf, sehingga diantara pengunjung terjalin saling memahami,dan saling membanlu.Misalnyasaja, kalau ada yang memotong kambing, biasanya gadis-gadis atau wanita-wanita muda yang kebetulan berkunjung akan datang membantu dengan suka rela terhadap keluarga yang akan mcmasak daging itu untuk disantap bersama.

Salah satu aspek yang menarik, bahwa proses pcrtemuan pengunjung di kompleks ini telah menciptakan satu pola interaksi tersendiri yang sangat unik.

Hubungan mereka biasanya diawali sccara kebetulan, karena duduk berdekatan, dan saling bcrtanya soal pribadi untuk mengisi waktu lowong scbclum naik ke kompleks makam. Kunjungan itu bisa intensif, kalau diantara mereka ada persamaan motivasi kunjungan. Misalnya saja mereka yang datang untuk cari jodoh, akan scgera akrab dengan teman-tcman lainnya, bila mengctahui maksud itu. Walaupun untuk kcpcrluan yang seperti itu, jarang diungkapkan ke luar, kecuali menjadi rahasia pembaca doa dan kcluarga yang bcrsangkutan. Dcmikian pula kelompok pengunjung yang datang hanya untuk melepas kaul, mereka akan cepat akrab dan hubungan itu biasanya bcrlanjut 
ketika sudah kembali ke daerah masing-masing. Sering kali ada hubungan saling mengunjungi tempat asal, apabila ada waktu, ketika mereka sudah kembali kekampung semula. Inilah beberapa faktor positif yang dapat meningkatkan solidaritas sosial pengunjung makam, yang tadinya berasal dari lalar bclakang gcografis yang berbeda bahkan sangat berjauhan, migrasi dari luar ini mempercepat proses pemukiman, setelah pendatang dari perkampungan sekitar Kerajaan Binuang (sekarang Kecamatan Polewali) menyusul dan membentuk lokasi pemukiman tersendiri disekitar lokasi makam Syekh bil Makruf.

Walaupun demikian sampai sekarang peta pemukiman tidak lagi diatur bcrdasarkan pola pengelompokan asal daerah pendatang, sebab terjadinya perkawinan campuran, dan tumbuhnya solidaritas baru, sebagai warga dusun telah mempercepat proses penyatuan warga dusun dalam konsep solidaritas baru, To Pulo.

\section{PERUBAHAN SOSIAL DI PULO TENGAH}

\section{A. Agama dan Perubahan Sosial.}

Setiap perubahan masyarakat tidak berdiri sendiri, demikian juga dalam abad ke-20 ini, perubahan masyarakat terjadi sebagai akibat penggunaan pencmuan-penemuan baru di seluruh dunia.

Sebab itu setiap perubahan masyarakat mempunyai wilayah inti (Karnland) dan wilayah tepi (Randland). Wilayah inti ialah wilayah yang merupakan sumber penyebab perubahan masyarakat, sedangkan wilayah tepi ialah wilayah yang mengalami perubahan secara merembes dari wilayah inti ke wilayahnya. Secara politis historis terbuktikan bahwa perubahan masyarakat dapat dihambat oleh beberapa negara karena mempunyai pemerintah absolut atau pemerin- tah kolonial. Perubahan akhirnya terjadi dengan berubahnya situasi politik dunia, khususnya di ncgara-negara yang sekarang dikenal sebagai negara berkembang. Di negara berkembang perubahan masyarakat terlambat pada permulaan abad kc-20 karena tradisi dan norma-norma masyarakat yang kuat (Astrid, 1983:162).

Robert L Sutherland, menilai bahwa terjadinya parubahan masyarakat karena manusia sebagai aktor perubahan adalah makhluk yang berfikir dan bekerja. Manusia disamping dia selalu berusaha untuk memperbaiki nasibnya. Dalam keadaan demikian, terjadilah scbabsebab perubahan, yaitu adanya inovasi (penemuan baru), invensi (penemuan baru), adaptasi (penyesuaian secara sosial budaya), dan adopsi (penggunaan dari penemuan baru/ teknologi). Kecuali itu orang yang berpendapat bahwa perubahan masyarakat terjadi karena keinginan manusia untuk menyesuaikan diri dengan keadaan di sekelilingnya atau di sebabkan oleh ekologi, dimana dianggap, bahwa persoalan perubahan masyarakat adalah hasil intraksi banyak faktor. Karena intraksi terjadi di segala bidang dengan sendirinya bukan saja perubahan terjadi dalam bidang sosial budaya tetapi juga dalam bidang ekonomi dan politik (Astrid; 165). Faktor-faktor lain yang menyebabkan terjadinya perubahan, adalah keadaan geografi tempat pengolompokan sosial, keadaan " $t^{\wedge}$ zlsik kelompok, faktor kebudayaan dan sifct anomi manusia salah satu faktor juga menjadi sebab terjadinya perubahan sosial dalam masyarakalialah agama. Terjadinya pergeseranpersepsi dan interpetasi penganut terhadap agama yang dianutnya, bisa menjadi alat pendorong terjadinya perubahan soal, dan kemudian akan menggcrakan bagian lainnya.

Peranan agama dalam konteks perubahan ini, dinilai para akhli sosiologi sebagai sangat fundamental, karena mencakup berbagai sum- 
ber atau faktor yang saling berkaitan. Astrid (1986). mengemukakan bagaimana manusia pada abad ke-20 ini mulai mengalami kecenderungan untuk berpaling ke agama. Sering terlupakan, bahwa kemajuan teknologi mempunyai akibat teknologi tidak dikuasai lagi oleh manusia dalam abad ke-20 manusia menjadi obyek dan bukan subyek tehnik. Akhirnya manusia tenggelam dalam alam yang dibentuknya sendiri, manusia menggantungkan nasibnya pada keadaan yang dibentuknya sendiri, dengan perkataan lain manusia tidak berdaya.

Karena putus asa, dan tidak mendapatkan lagi pegangan yang bisa menenteramkan jiwa, manusia mulai berpaling kepada agama. Proses kembalinya kepedulian manusia terhadap agama, bisa dimanefestasikan dalam bentuk puritanisme, atau bisa juga dalam wujud transformasi. Pada masyarakat yang masih terisolasi oleh beberapa faktor, yang belum dapat dipecahkan karena keterasingan geografis, sistim sosial budaya yang beum bisa menerima pesanpesan dari luar komunitas kepedulian terhadap agama, muncul tidak dari proses keputus asaan tetapi karena ketcrgantungan kepada alam, dan teknologi rendah, mereka tidak mampuh menghadapi keadaan-keadaan yang menggetarkan, termasuk ketidak mampuan menghadapi kodrat dan hukum alam. Penderitaan rasa sakit, dan kematian, serta bencana-bencana berat yang menimpah kehidupan mereka, akan mendorong mereka untuk lebih dekat kepada agama dan cenderung untuk menggunakan komunikasi mistik dalam pendekatan-pendekatan dengan Tuhan.

Proses perubahan yang terjadi di lingkungan masyarakat Pulo Tengah, dan kepedulian yang tinggi terhadap agama (ritual mistik). bcrlangsung secara gradual, melalui pengalaman pribadi dalam kegiatan keagamaan, dan karena adanya kontak-kontak intensif antara pengun- jung makam dengan penduduk setempat.

Secara teoritis, proses perkembangan masyarakat Pulo Tengah, dan ketergantungan mereka pada keadaan alam, laut dan kondisi geografis daerah pemukiman, menyebabkan, keterikatan terhadap agama cukup tinggi.

Agama dalam kaitan ini, telah menjadi unsur perekat dan memupuk solidaritas masyarakat, schingga mereka bisa hidup dengan tenang di Pulo dan secara rutin memelihara simbol-simbol relegius khas Pulo, yaitu Makam keramat.

Di lain pihak, keyakinan terhadap agama, dengan kualitas pemahaman yang sangat terbatas, seringkali menjadi unsur penghambat proses adaptasi mereka terhadap inovasi dari luar, meskipun hal itu bermanfaat secara ekonomi. Sebagai contoh, bagaimana ekonomi subsistensi bertahan cukup lama di lingkungan masyarakat. Bekerja sebagai nelayan, hanya sekedar untuk bisa hidup sendiri, dan hasil langkapan setiap hari, hanya dijual untuk memenuhi kebu tuhan subsistensinya. Usaha untuk moningkatkan hasil tangkapan menjadi sumber produksi komersial, yang dapat menambah pendapatan penduduk tidak pernah dikembangkan secara programatis.

Pada bulan Januari 1990, seorang pengusaha rumput Laut dari Binuang datang ke Pulo Tengah, untuk mengajak masyarakat nelayan agar dapat bekerja sama dalam pertanian rumput laut. Selain mengemukakan hasil yang diperoleh kalau berhasil, pengusaha ini juga menjanjikan untuk menampung dengan pembayaran kontan setiap produksi rumput laut yang dapat dipanen. Untuk mencapai tahap operasionalnya, idea pengembangan rumput laut, itu belum mendapat respons yang bcrarti dari masyarakat. Nelayan setempat, bahkan lebih suka menekuni pekerjaan sehari-hari, menangkap ikan di laut dan kemudian pulang kerumah. 
Ide ini, hanya di terima beberapa orang pemuka masyarakat termasuk Kepala Dusun, tetapi tidak dilaksanakan oleh perangkat syara' seperti Katte dan Imam.

Perangkat syara', ketika di wawancarai terhadap ide pengembangan rumput laut, tidak menyatakan penolakan secara resmi, tetapi bersikap hau-hati. Apalagi, ide tersebut belum dapat diamati hasilnya secara konkerit. Sebenarnya, bukan masalah agama yang menjadikan perangkat syara' ini belum mau beradaptasi dengan ide rumput laut itu, tetapi secara kebetulan, keterlibatan mereka terhadap upacara siarah ke makam Syekh bil Makruf yang berlangsung setiap harinya menyita waktu mereka untuk melakukan kegiatan-kegiatan "sekuker" lainnya.

Kasus seperti ini, adalah pengalaman Pajarai. seperti dikemukakan kepada Peneliti dalam wawancara di kompleks makam :

"Saya sudah sepuluh tahun menjadi pendamping Machfud (Katte atau Khatib yang juga berf ungsi membacakan doa di kompleks makam, bagi setiap pensiarah). Setelah Macfud meninggal tahun lalu, saya langsung dipercayakan masyarakat untuk menggantungkan tugas ini. Pada hal, sebenarnya saya bermaksud untuk memulai usaha kecil-kecilan, dengan menjual barang campuran di Dusun ini. Karena pengangkatan saya sebagai Katte, tugas tersebut tidak bisa saya lakukan. Tugas Keagamaan ini, menghabiskan waktu. Apalagi jumlah pengunjung hampir tidak pemah berhenti.

Baru-baru ini, petugas Suaka Sejarah dari Ujung Pandang datang ke mari. Mereka menyuruh saya memasukkan berkas permohonan untuk diangkat jadi pegawai negeri. Saya kemudian tanyakan kepada mereka, apakah pengangkatan pegawai negeri tidak akan menghalangi tugas ini untuk merawat makam.

Kalau akan menghalangi, jelas tidak bisa. Kecuali kalau hal itu bisa mendukung tugas yang dipercayakan masyarakat Pulo, sebagai Katte, tentu permintaan itu akan saya penukit dengan senang hati".

Salah satu tujuan utama, orang Pulo, terutama yang sudah menetap di sana selama sepuluh tahun, adalah bagaimana mereka bisa menjadi warga dusun yang baik, dan bisa riienyediakan waktu untuk "mengabdi kepada kepentingan agama. Bagi penduduk dusun, ikut serta merawat makam membersihkan dari rumput-rumput liar, atau membersihkan jalanan yang mcnuju ke atas bakit makam dari sampan dan batu-batu kecil yang berserakan, adalah berarti pengabdian keagamaan. Sebaliknya, sebagai orang yang bersifat acuh tak acuh terhadap makam Syekh bil Makruf.

B. Perubahan yang Terjadi

Kontak pertama penduduk Pulo Tengah, dengan masyarakat pendatang terjadi sekitar akhir abad ke-17. Diperkirakan, sejak meninggalnya Syekh bil Makhruf, secara "aneh" di pesisir pantai Pulo Tengah ini, pada akhir abad ke-17, dan setelah dimakamkan di Pulo itu, sejumlah pengikutnya dari Binuang mulai menempati Pulo itu sebagai tempat pemukiman.

Tradisi yang berkembang dari pengikut Syekh bil Makruf di sekitar Pulo, setelah tokoh panutan itu meninggal, menurut kepercayaan penduduk yang ada sekarang, seperti melakukan sholat tarwih 20 rakaat pada bulan puasa, menyelenggarakan azan dua kali pada harijumat, qun ut pada waktu subuh, dan membaca doa di depan makam, semuanya adalah tradisi yang diwarisi secara turun temurun.

Tradisi itu, kemudian mengalami persentuhan dengan terjadinya kontak penduduk setempat dengan para pendatang, banyak pengunjung yang datang dari jauh, dan tidak sempat pulang setelah melakukan siarah, terpaksa bermalam di rumah-rumah penduduk. Ada juga yang bermalam sampai tiga malam, karena 
rangkaian upacaranya memakan waktu yang agak lama. Pada malam hari, pengunjung yang dianggap mempunyai pengetahuan agama yang memadai, di undang ke masjid dan di persilahkan memberikan ceramah agama antara magrib dan isya. Kadangkala, ada yang memberikan ceramah tambahan pada waktu subuh. Pesan-pesan khusus yang disampaikan lewat ceramah dari pengunjung yang datang ke mari, secara khusus telah menimbulkan pcrgeseran wawasan penduduk dalam berbagai masalah keagamaan. Sejak tahun 1970 an, pengurus masjid Pulo Tengah, biasa mengundang penceramah dari luar Pulo untuk datang ke Masjid Dusun. Sebelumnya, sikap seperti ini tidak pernah dilakukan, karena mereka menganggap bahwa tradisi muslim yang final dan sempurna, adalah yang ditinggalkan "Tosalama Syekh bil Makruf. Karena itu, selama beberapa puluh tahun, dan bahkan sampai ratusan tahun setclah meninggalnya, tidak ada tradisi yang ditinggalkan Tosalama yang mengalami perubahan yang berarti. Bahkan, usaha untuk melakukan perubahan dari pewarisan dan tradisi yang sudah dianggap mapan, adalah pengingkaran yang bcrbahaya.

Penduduk Pulo yakin, bahwa mereka akan mendapatkan hukuman, baik beiupa bencana alam, kematian, penyakit dan sebagainya manakala melakukan scsuatu yang tidak dikehendaki oleh Syekh bil Makruf. Komitmen penduduk terhadap tokoh ini, sclama dua abad lebih menjadi konsep yang dipegang teguh, tanpa mengalami perubahan sedikit pun.

Terjadinya perubahan ini, memperlunak sikap anggota masyarakat terhadap pendatang dari luar. Di samping itu, terjadi pcrgeseran sikap masyarakat terhadap arus pengunjung. Kalau sebelumnya, mereka memahami kedatangan pengunjung sebagai kegiatan religisu, karena merupakan penghormatan terhadap
Ayah bil Makruf, akhir-akhir ini, terasa bahwa sudah mulai ada kecenderungan ekonomis masyarakat, untuk memanfaatkan arus pengunjung yangcukupbesar. Dalam lima tahun terakhir, petugas makam sudah memasang kotak amal di tempat peristirahatan di kaki bukit, sebclum naik ke tangga untuk menuju kompleks makam. Kota amal itu, adalah untuk menampung sumbangan setiap pengunjung, dan hasilnya akan digunakan merawat makam, dan sebagainya di distribusikan pada pembangunan masjid Dusun.

Pcrgeseran persepsi, masyarakat dari aspek rcligisistas murni ke aspek ekonomis ini, kalau diprogramkan, dapat memberi nilai tambah bagi masyarakat setempat. Pekerjaan yang menonton, sebagai nelayan sangat tergantung pada keadaan cuaca. Dan pada saat-saat tertentu, mereka tidak bisa ke laut. Dan pada waktuwaktu seperti ini sebenarnya bisa digunakan untuk memanfaatkan kedatangan pengunjung dengan mempersiapkan pclayanan yang dibutuhkan. Hasilnya, Penyediaan kendaraan penyebcrangan siap jalan, penyewaan tikartikar khusus, sebagai alas tempat duduk, dan kalau perlu bantal dan kasur disewakan kepada pengunjung bagi mereka yang ingin istirahat sebelum kembali ke Bajoe.

Perubahan sikap terhadap pendidikan juga sudah mulai tumbuh. Di Dusun ini sudah ada sebuah Madrasah Ibtidaiyah, yang dapat menampung anak-anak usia sekolah dasar untuk jenjang pendidikan dasar. Kepercayaan masyarakat terhadap madrasah ini sangat tinggi, sehingga rala-rata anak usia sekolah dasar yang tinggal di Pulo Tengah, menyelesaikan pendidikan dasarnya di Madrasah Ibtidaiyah. Perubahan sikap masyarakat terhadap pendidikan anak, juga di tandai dengan semakin banyaknya putra-putra asli Pulo Tengah yang melanjutkan pendidikannya sampai ke tingkat SMA di Polewali. Mala ada, beberapa orang yang sudah 
melanjutkan study ke Perguruan Tinggi di Ujung Pandang.

Sebab-sebab terjadinya perubahan sikap terhadap pendidikan ini antara lain karena terjadinya kontak intensif antara pengunjung dan penduduk setempat. Salah seorang pemuka Tariqat Naqsabandiyah yang menjabat sebagai Dekan salah satu Fakultas di Ternate, sangat akrab dengan penduduk setempat, karena yang bersangkutan seringkali datang ke Pulo Tengah. Ceramah-ceramah agamanya di Pulo ini, dan usul-usulnya yang disampaikan secara lisan kepada pemuka masyarakat secara tidak langsung menjadi cikal bakal penunjang terjadinya perubahan sikap masyarakat terhadap pesan-pesan pembangunan, agama dan pendidikan.

Dalam situasi yang berlawanan, secara ekologis, perubahan tidak begitu nampak. Rumahrumah penduduk, hanya mengalami bcberapa peningkatan simbol-simbol ekonomi pemiliknya, tetapi hanya dalam persentase yang minim. Jalanjalan penghubung dalam dusun masih seperti sebelumnya. Untuk menjangkau pemukiman penduduk beberapa tempat yang terpisah, masih harus jalan kaki. Kendaraan, mulai sepeda, sepeda motor, atau kendaraan angkutan darat lainnya belum digunakan di dusun ini. Pembangunan jalan antara RT dan RK, belum terjangkau, dan fasilitas perawatan medis dari Puskesmas juga sangat terbatas.
Listrik, sebagai salah satu indikator pembangunan desa, juga belum masuk ke dusun ini. Faktor biaya, dan rendahnya kemampuan ekonomi penduduk dusun, mungkin merupakan salah satu faktor mengapa pengembangan aliran listerik dengan tenaga pembangkit skala kecil, belum menjangkau Pulo Tengah.

Salah satu faktor yang tidak dapat dimungkiri, bahwa proses pembaharuan dalam masyarakat akan berjalan secara bertahap. Masuknya "agen" pembaharuan, seperti kader-kader mahasiswa KKN Penyuluh agama, dan penyuluh perikanan, serta distributor pengusaha rumput laut yang secara intensif menggarap partisipasi penduduk dalam pembudidayaan rumput laut, walaupun belum mendapalkan responsi yang mcmadai, pada suatu saat akan meninggalkan pengaruh yang cukup besar terhadap masyarakat dan akan membuat jarak isolasi mereka dari masyarakat di luar Pulau akan menjadi lebih dekat. Misalnya, tinggal menunggu waktu saja, gagasan-gagasan pembaharuan, dan penerapan tcknologi perikanan serta penggunaan teknologi baru berupa motorisasi perahu nelayan, secara bertahap akan mcmbuka tabir ketcrasingan masyarakat, dan membawa mereka dalam komunitas yang lebih terbuka, dan bisa beradaptasi dengan pembangunan daerah yang berlangsung di sekitarnya.* 